Comparative Philosophy Volume 5, No. 1 (2014): 29-54

Open Access / ISSN 2151-6014

www.comparativephilosophy.org

\title{
THE INCLUSIVE DYNAMICS OF ISLAMIC UNIVERSALISM: FROM THE VANTAGE POINT OF SAYYID QUTB'S CRITICAL PHILOSOPHY
}

\begin{abstract}
ANDREA MURA
ABSTRACT: This article pursues a topological reading of Milestones, one of the most influential books in the history of Islamism. Written by Muslim thinker Sayyid Qutb, the general interest in this crucial text has largely remained restricted to the fields of Islamic Studies and Security Studies. This article aims to make the case for assuming a philosophical standpoint, relocating its significance beyond the above-mentioned fields. A creative and topological reading of this text will allow the spatial complexity of Qutb's eschatological vision to be fully exposed, while also unpacking the way in which antagonistic relations have variously been articulated by this thinker. The underlying conviction is that such an examination can offer new perspectives from which to examine and develop current debates on political universalism and antagonism in the tradition of continental philosophy.
\end{abstract}

Keywords: topology, antagonism, universalism, Islam, territoriality, Sayyid Qutb

\section{INTRODUCTION}

The question of universalism - for all its attendant complexities and ambiguities - is on the intellectual agenda again. One should acknowledge, for instance, Žižek's defence of universalism against globalisation; that is, the universalistic endorsement of a space for political litigation against the multicultural ideology of a peaceful global order (Žižek 1999). Similarly, Badiou's engagement with St. Paul's universalism has been central to philosophical debate (Badiou 1997/2003) whereby religious universalism has been instrumental to rethink lay forms of political action in what has been called a "communist appropriation of Christianity" (Coombs 2009, 1).

This article finds inspiration in this question. The ambition from the outset is to widen the spectrum of political reflection, enriching the speculative analysis of lay and Christian forms of universalism with an insight into Islamic universalism. Although this rejuvenated interest in the notion of universalism has brought the

MURA, ANDREA: Research Associate, Oecumene Project, Open University, UK. Email: andrea.mura@open.ac.uk 
concept to the centre of academic debate in Europe, a gap in the examination of nonWestern traditions has in fact marked such a discussion, leaving similarities and differences among speculative notions of "universal" space and community substantially unexplored. In an attempt to confront the potential risks of Eurocentrism of political theory (Thomas 2010, 654), this article will pursue a critical analysis of Sayyid Qutb's Milestones, one of the most influential books in the history of the twentieth-century Sunni Islamic political movement, proposing a topological reading of this crucial text.

Defined as the "ideologue of Islamic revival" (Haddad 1983; Musallam 2005), Sayyid Qutb (1906-1966) has been one of the most prominent thinkers in the Muslim world. Qutb incarnated a difficult moment in Islamist history, a phase, between the 1950 s and the 1960s, characterised by the wide repression of Islamist movements by Arab regimes, and by the quasi-dormancy of Islamist action. While his execution by the Nasser regime in 1966 was testament to the difficulty of this phase, his discourse anticipated, beyond any ambiguity, the attempt to revitalise the Islamic tradition in what has been called the "rejuvenation", "revival" or "return" of Islamism in the 1970s (Lewis 1976; Mandaville 2007). His vision was central in challenging "the imposition of a monolithic Arab nationalist-socialist discourse on Egyptian society", therein countering the dominant role that nationalism played during this time (Moaddel 2005, 218). The exemplary value of his thought, however, transcended the social and historical context. His last work, translated either as Signposts on the Road or Milestones, (Ma'alim fi-l-Tariq) and published in 1964 (Qutb 1964/2006), has had a massive impact on several generations of Muslim activists and believers, influencing the way that antagonistic relations have been articulated by many Islamist groups (Calvert 2010). This has been true, in certain respects, for organisations such as the Muslim Brothers whose political focus has rested primarily on the reformation of domestic politics, not a universal Muslim community. Milestones's influence, however, has also been felt in the formation of transnational views of those such as bin Laden, inspiring the particular antagonistic position that so-called "neofundamentalist" groups have assumed in recent decades in what they often perceive as a globalised and post-national world (Roy 2004). Described as "one of the most widely read and controversial Arab books of the twentieth century", Milestones stands as Qutb's political manifesto (Starrett 2004, 55). In both its concision and clarity of argumentation, the text has represented a potent tool of political mobilisation. As Roxanne L. Euben puts it: "Qutb's thought can serve as a window into the world of contemporary Islamic fundamentalist political practice; as Qutb's most influential and radical book, Signposts is the text that has significantly influenced such practice" $(1999,56)$.

In this general context, references to Sayyid Qutb have largely remained restricted to the fields of Islamic Studies and Security Studies. ${ }^{1}$ While important works have

\footnotetext{
${ }^{1}$ Security Studies is generally understood as an area of inquiry in post-Cold War international relations examining the challenges to international security related to organized violence, and the sources and conditions of war and peace.
} 
been published recently that have scrutinised distinct aspects of Qutb's theoretical position (references will be offered in the following pages), they mostly aimed at assessing the impact of Qutb's theory on Islamic political practice rather than considering it in the light of broader philosophical debates in the critical humanities. An Islamic studies audience has mostly remained the target for such remarkable endeavours, replicating the positioning of Qutb in the "area" of Islamic studies. Aside from these contributions, a quick Internet search shows that Sayyid Qutb's name is also predominantly associated with analyses on global jihad, terrorism, and political violence. This tendency has certainly been reinforced post-9/11 with the coming to prominence of Islamist organisations on the stage of world politics. Sayyid Qutb's role as an ideologue of contemporary Islamic movements has thus taken precedence over the more analytical aspects of his theory.

This article aims to make the case for assuming a philosophical standpoint in the analysis of Sayyid Qutb's Milestones, relocating its significance beyond the abovementioned fields. The objective is to pursue a creative and topological reading of this crucial text, allowing the spatial complexity of Qutb's eschatological vision to be fully exposed, while also unpacking the way in which antagonistic relations have variously been articulated. The underlying conviction is that such an examination can offer new perspectives from which to examine and further develop the debate on universalism and contemporary forms of antagonism. In asking the reader to follow me in this article, I will strive to maintain a language accessible to an Islamic Studies non-specialist, resorting to concepts and categories widely used in continental philosophy (contingency, necessity, antagonism, vanguardism, etc.). Thus a certain effort of cultural translation will be enacted, in relation to which a few caveats are required.

Firstly, in attending to texts from outside a "Western tradition", this article does not want to neglect the indeterminacy of concepts such as East and West or dismiss the on-going fluctuation and circulation of ideas that underpins their very symbolic constitution as discursive categories. This attempt is rather to point to the hegemonic empowerment that these concepts instantiate, contributing to develop what has been called "an epistemology of the South" (Santos 2007). This topological examination of Milestones aims therefore "to uncover" forms of knowledge that were masked, concealed, silenced, or simply ignored by juridico-political discourses over citizenship, accounting for ideas of territoriality and community in non-Western sources (Isin 2012). Secondly, to engage in such a considered explanation entails leaving a comparative analysis between Qutb's and continental ideas of universality aside from this article. The choice here is to postpone a close scrutiny of their similarities and differences for future investigation. Such a comparison would not only detract space from the kind of in-depth examination of Milestones that will be proposed here, but would also benefit from assuming, as a point of departure, the different observations that will be made. That said, it is important to briefly explain the wider political and intellectual significance of Milestones for an Islamic Studies non-specialist audience, and the utility of the following topological reading. A salient trait of Qutb's universalism can be located in its ability to imagine a form of 
universalistic space marked by inclusive antagonistic dynamics. At first instance, to uncover this spatial configuration in this article will help to grasp Qutb's counterhegemonic use of Islamic universalism vis-à-vis dominant discourses on nationalism in his post-colonial times, therein assessing the territorial specificity of this tension. But an insight into this spatial model in Milestones, will also contribute to the continental critique of a so-called "post-ideological" world and the multicultural promise of a "peaceful" global order "with each part in its allocated place" (Žižek 1999, 200).

As widely discussed over the last two decades, the increasing demise of partypolitics, the growing relevance of technocratic and managerial problem-solving procedures in institutional arenas and the discursive emphasis on the ability of late capitalism to accommodate social tensions by way of consensus-seeking procedures which render social conflict unnecessary and ideological divisions obsolete - have all informed neo-liberal discourses in different degrees (Ranciére 1999; Hardt and Negri 2000; Badiou 2006; Žižek 1999). Although the recent financial crisis seems to be challenging this long-standing process, for years the mantra of a "post-ideological" world has contributed to a de-facto de-politicisation of society and the demobilisation of democratic struggles in what has been called the "end of politics" (Rancière 2007, 6). According to Žižek, postmodernist theory, with its emphasis on "multiculturalism" and "identity politics", has contributed to excluding the very idea of political struggle. By reformulating systemic problems as personal issues and promising to offer an exhaustive account of individual or particular demands, postmodernism has reinforced the promise of a cosmopolitan future of harmony and prosperity. This helped to demobilise resistance and political conflict, strengthening hegemonic power relations (Mouffe 2005).

From a psychoanalytical perspective, conflict plays a central function in the organisation of social relations in that it allows the subject to symbolise and channel the tension with alterity. Such a tension is somehow unavoidable and constitutive of the subject, marking the ever-precarious relation between the self and the other. Discourse on the promise of perpetual peace, without any need for confrontation, ends up neglecting the social function of conflict, its ability to allow for a symbolic relation with the other through which difference can be mediated in a dialectical and productive way. Erasing conflict from the social and political vocabulary has coincided with the increasing difficulty to symbolise and channel the relation with the outside, allowing this tension to emerge in the form of "violence". This tendency is well reflected in Žižek's analyses of contemporary outbursts (Žižek 2008a), or Chantal Mouffe's assertion that the liberal prevention of disagreement, together with its denial of discontent, has allowed for the development of violence and terrorism (Mouffe 2005). In this context, Milestones's universalism reveals the emergence of a complex dynamics, which is rooted in the upholding of a "permeable" idea of limit between inside and outside, the citizen and the non-citizen, allowing for forms of inclusion of the outside that mediate the ever ambivalent relation with exteriority.

Although crucial differences exist between Qutb's counter-hegemonic universalism and continental accounts of universality, to which I will briefly hint at in 
the conclusion, to examine the inclusive dynamics of Qutb's universalistic vision is useful in consideration of the debate on the de-mobilising effects of neo-liberal postpolitics. In this respect, this topological reading will help unfold the multidimensionality of Qutb's antagonistic model and his way to account for conflict. Moreover, it will also contribute to the general debate on universalism providing it with a spatial representation of what a universal surface could look like, within which enduring flows and transformations can be accounted.

In fields as different as cultural geography, political theory and psychoanalysis, an increasing use of topology has attempted to consider space using metaphors of proximity, closeness, neighbourhood and transformation rather than simply distance. With its emphasis on holes and sutures and its attention for qualitative traits rather than quantitative properties of geometrical structures such as lengths, degrees, and areas, topology has offered crucial tools for critical investigations. In the humanities, this has allowed for consideration of complex structures in their totality, addressing elements of contiguity and transformation and producing new ways of representing and problematising subjectivity formations. A topological analysis will prove then to be essential in exposing the spatial and temporal complexity of Milestones. It will be the task of this article to uncover the multifaceted dynamics of Qutb's universalism, its internal flows and movements between specific planes such as: inside and outside; necessity and contingency; and reality and virtuality.

\section{SAYYID QUTB'S NORMATIVE VISION}

In her noteworthy study of Qutb's political theory, Euben interprets Milestones as a tripartite analysis of contemporary political communities. According to Euben such an analysis would consist of a "diagnosis of the ills of modernity (jahiliyyah), a cure (rebellion, followed by the establishment of sovereignty based on Islamic law), and a method of implementing the cure (organising a counter-community, jama' $a$, and spreading it through jihad" $(1999,56)$. In the following textual examination of Milestones a different organisation of this structure will be proposed, entailing critical differences in terms of spatial and subjective configurations. According to this reading, a twofold dimension, embodying both a descriptive and a normative register, informs Qutb's view of the human condition in Milestones. On the one side, Qutb provides a critical description of the contemporary predicament in which mankind lives, something akin to the level of diagnosis in Euben's analysis. On the other side, a discussion of how humanity should be and live according to human nature, as it was created by God, intersects with the descriptive level. This latter register entails a dimension somewhat irreducible to the former, and placed on a different temporal and spatial "plane". An inquiry into these two spatial dimensions is essential to distinguish between different forms of antagonism in Qutb's discourse.

The basic norm to establish how a society should be, therein acceding a normative level of analysis, is best exemplified by a passage where Qutb defines Islamic society as "that which follows Islam in belief and ways of worship, in law and organization, in morals and manners" $(1964 / 2006,93)$. At a first general level, the realm of Islam is 
qualified by a particular definition of "sovereignty" (hākimiyya) as derivative of God's will on earth, and its fundamental equation with two other main signifiers: "freedom" and "human civilisation":

When, in a society, the sovereignty belongs to God alone, expressed in its obedience to the Divine Law, only then is every person in that society free from servitude to others, and only then does he taste true freedom. This alone is "human civilization" (Qutb 1964/2006, 94).

This passage evidences the central position played in Qutb's articulation by the notion of "sovereignty", and by the particular semantic relation that such a signifier establishes with "God". It is this relation that gives "sovereignty" its specific connotation, differentiating it from alternative notions of sovereignty, and thereby enacting the possibility for "freedom" and "human civilization" to be realised at all. With alternative notions of sovereignty, I refer in particular to its specific rendering in modern political thought. In continental juridical doctrines, sovereignty had been conceptualised as the supreme "power" (summa potestas) giving "force" and "authority" to a political order by way of its "absolute and perpetual" (Bodin), "exclusive and indivisible" (Hobbes) essence. The supreme power of a political order was thought of, therefore, as the original, unrestricted and unique source of legitimacy of state control, which does not recognise any superior principle of power outside itself. Among early Islamist trajectories, for instance in the discourse of Hasan al-Banna - the founder of the Muslim Brothers, there had been a certain tendency to re-articulate the notion of "sovereignty" along modern lines. This implied depriving "sovereignty" of its transcendental character and re-directing it from God to the immanent power of the people of the nation. As al-Banna put it: a "truly Islamic government" was one performing "as a servant to the nation in the interest of the people" (al-Banna 1940s). Unlike al-Banna, Qutb articulates God's sovereignty in purely transcendental terms. This means that even in cases where Islamic society takes the form of a state, such a juridical construction would remain substantially alien to the model of the nation-state. In this scenario, the Islamic government would find its inner legitimisation outside itself; that is, in God rather than in the immanent power of the state or the people of the state (as with modern sovereignty). Hence, a certain downplaying of the very notion of Islamic state in Qutb and the prioritisation of an Islamic community devoted to the direct application of the shari'ah.

The definition of sovereignty in transcendental terms entails a double movement. On the one side, his traditional reading of sovereignty implies an upward re-directing of sovereignty from humankind to God:

They [Arabs] knew that "uluhiyah" means "sovereignty", and they also realized that ascribing sovereignty only to God meant that the authority would be taken away from the priests, the leaders of tribes, the wealthy and the rulers, and would revert [emphasis is mine] to God (Qutb 1964/2006, 24). 
This position is reinforced by another statement in which Qutb expressly rejects the possibility of having not only lay but also religious authorities incarnating or interpreting Islamic law, while suggesting a strict and literalist application of the shari'ah.

The way to establish God's rule on earth is not that some consecrated people - the priests - be given the authority to rule, as was the case with the rule of the Church, nor that some spokesmen of God become rulers, as is the case in a "theocracy". To establish God's rule means that His laws be enforced and that the final decision in all affairs be according to these laws (Qutb 1964/2006, 58).

On the other side, an extensive and horizontal movement allows Qutb to state the traditional Islamic significance of sovereignty as embodied by Islamic law, depriving it of all modern interpretations that have reduced shari'ah to a matter of legal injunction:

In Islam the meaning of the "Shari'ah" is not limited to mere legal injunctions, but includes the principles of administration, its system and its modes [...] Similarly, it includes political, social and economic affairs and their principles [...] It deals with the morals, manners, values and standards of the society, according to which persons, actions and events are measured (Qutb 1964/2006, 107).

When defined in this way, shari'ah expresses an all-inclusive and integral conception of life. This is particularly important considering that Qutb is adamant in defining an Islamic society in traditional terms assuming a universal conceptualisation of ethics, which is not reduced to the logic of public interests. A society in which sovereignty is taken to express God's will, needs then to be articulated in an ethical model involving every aspect of human life (Khatab 2002; 2006). In his biography of Qutb, John Calvert argues that Qutb's reliance on a "Qur'anically justified concept of God's judgment and dominion" aimed to "undermine the theory and practice of state sovereignty which undergirded the Western-dominated global order" (Calvert 2010, 215). From this perspective, Qutb's eschatological vision is intimately related to the political dimension of his universalism. The counter-hegemonic potential that Qutb ascribes to his universalistic conception of human society vis-à-vis the discourse of the nation, a discourse playing a dominant role in Middle Eastern societies during his times, is therefore central to understand the specificity of his vision.

From a general perspective, nationalist discourses can be identified for the fundamental link they establish between three key signifiers: "sovereignty", "territory" and "the people", whose articulation, I contend, is intimately related to a binary conceptualisation of space and subjectivity. In regard to "sovereignty", we have seen that Qutb deploys a transcendent reversion from humankind to God, and that this movement also implies an integral and horizontal expansion of sovereignty undoing the secular dichotomies such as those between private and public, political and religious. Qutb's rejection of national signifiers, however, is also evidenced by 
the dismissal of the modern concepts of "territory" and "people" in favour of traditional signifiers like dar al-Islam and the ummah.

At first glance, Qutb's assumption of a fluid and inclusive notion of community in the form of the so-called ummah marks the difference with its nationalist counterpart, "the people". In examining the historical process leading to the formation of European nations, the identification of local populations with the signifying image of the people has entailed the articulation and mobilisation of a strict dualism (Delanty 1995; Balibar 1991; Young 1995). Hardt and Negri, for instance, noticed that the construction of the national people entailed overemphasising similarities in blood, language and history while, at the same time, subsuming differences within the unitary spiritual dimension of the people (Hardt \& Negri 2000). An indivisible sacred Self was thus constituted which was put in radical antagonism with all that remained external to it.

A point of differentiation can thus be detected in this respect when considering the Islamic notion of ummah, as the representation of the Muslim community had traditionally required a strong symbolic emphasis on a notion of integration. The inclusive stance of the ummah was celebrated through the reference to the variety of ethnic groups that, at different times, took pre-eminence over the ummah, assuming the historical role of its diffusion and expansion as in the dominion of Arabs, Mongols, Turks and so on. Talal Asad, for instance, claims that members of every community imagined the Muslim ummah to be grounded in a specific normative character and related to each other on the basis of that feature. "The crucial point therefore is not that it is imagined but that what is imagined predicates distinctive modes of being and acting" (Asad 2002, 197). This means that while functioning as a universal abstract principle, the ummah was grounded in a multiplicity of differing actualisations, each one defining a "particular" (cultural, historical), self-governing "mode of being" of that universality. In other words, the inclusive universality of the Muslim community stood for its ability, in principle, to include differences. Its oecumene did not dissolve its internal distinctive dynamics, but articulated them as a multiplicity of singularities expressing their historical and cultural manifestations.

Qutb's alignment to a fluid conception of ummah, which in its vocabulary is also called the "Islamic society", is unequivocal. In a short passage, he formulates his position in explicit terms:

Islam based the Islamic society on the association of belief alone, instead of the low associations based on race and color, language and country, regional and national interests [...] Among the concrete and brilliant results of this attitude was that the Islamic society became an open and all-inclusive community in which people of various races, nations, languages and colors were members, there remaining no trace of these low animalistic traits (Qutb 1964/2006, 49).

From a normative perspective, therefore, a perfect Islamic society should be "an open and all-inclusive community" [emphasis mine] integrating all differences within its multiplicity. This implies thinking of the Islamic community as an immediate and 
inclusive presence, and then rejecting various forms of nationhood as "low animalistic traits". It is important to stress that, defined like this, such a conceptualisation of the ummah reflects a state of necessity. That is, Islamic society alone allows "humanity" to emerge and develop. It figures as a necessary condition for the very realisation of "humanity"; the absence of this condition would qualify human life as a mere "animalism":

In whatever society Islam is dominant, whether it is an agricultural or industrial society, nomadic and pastoral or urban and settled, poor or rich, it implants these human values and morals, nurtures them and strengthens them; it develops human characteristics progressively and guards against degeneration toward animalism (Qutb 1964/2006, 97).

In his recent analysis of Qutb's ethical model, Andrew March drew from Rawls the concept realistic utopia to describe a comprehensive theory of political life that "not only posits a true doctrine of the good or the right (i.e., the substance of moral obligation for persons and societies), but also contains an account of how that theory does not contradict what we know about human moral psychology" (March 2010, 192). From this perspective, to define Islamic society as a necessary condition means to point to the immediate adaptability and convergence that Qutb instantiates between humanity and the ethical and normative framework that God has reserved for it. This is central to operate a disjuncture between the uniqueness of the Islamic normative system, which only responds to humans' own characteristics, and other normative systems that alter the very "human" quality of mankind. The state of necessity that Islamic society incarnates entails in fact the assumption of a universalistic and inclusive approach to subjectivity, which overcomes the particularistic features that nationhood is said to involve with its emphasis on "low associations". It only preserves the spirit of the human genre preventing its degeneration into animalism. From this perspective, the refusal of national affiliations, from local forms of belonging to pan-Arab or pan-continental loyalties implies, for Qutb, formulating communitarian ties not on the basis of geographical adjacency or biological traits (lineage or race), but as a commonality of choice and belief.

This marvellous civilization was not an "Arabic civilization", even for a single day; it was purely an "Islamic civilization". It was never a "nationality" but always a “community of belief" (Qutb 1964/2006, 49-50).

A further element of differentiation from the discourse of the nation is reflected in Qutb's reactivation of the traditional concept of dar al-Islam vis-à-vis the idea of national territory. Again, in considering the historical process leading to the formation of the modern nation-state, the intimate link existing between a dualistic logic and the national concept of "territory" has been amply debated. Foucault, for instance, pointed to the increasing process of rationalisation of land occurring during the consolidation of the modern state, which ended up entailing a necessary and exclusionary model of space, as the end of my territory necessarily coincides with the beginning of yours (Foucault 1977-1978/ 2007). Hence the radicalism of precise and 
definite national borders demarcating a clear-cut, shared, and necessary distinction between $u$ s and them.

In traditional universalistic terms, instead, the Islamic conception of territoriality was articulated through the notion of dar al-Islam (the "domain of Islam"; also referred to as "abode of belief"). Although this was introduced by a number of jurists as a label of classification and was not a proper Qur'anic term, nor was it a new concept in medieval times (it somehow resonates with the universalistic notion of Res Publica Christiana), it ended up playing a central function in organising Islamic jurisprudential thought about territoriality. Manoucher Parvin and Maurie Sommer tracked the line of theoretical and historical development of what they saw as the "dynamic, accommodating processual notion of dar al-Islam" (1980, 18). These authors considered Islamic territoriality to be based on "interaction patterns human, environmental, systemic" so that, because of "context- and timedependence", its integrity relied on a sort of "spatial response" and not "spatial immutability" (1980, 2). Dar al-Islam remained for a long time inclusive and accommodating, regulated by difference and integration, with an outside (nonMuslim lands in the form of dar al-harb) treated as a temporary differential space to be subsumed under the banner of the Islamic universalism. Early jurists of Islam, however, had to acknowledge the existence of lands ruled by non-Muslims. While the juridical notion of dar al-Islam was used to define the domain of faith and to designate Islamically-ruled countries, the notion of dar al-harb (the abode of war or chaos) began to be deployed for any land outside Muslim jurisdiction. Although in classic universalistic formulations of dar al-Islam discourses present differences over time, here the outside expressing the domain of unbelief - the dar al-harb - is not so much a constitutive and necessary space for the very articulation of dar al-Islam. It rather reflects a contingent factor to be subsumed and integrated within the universality of Islam.

In Qutb's normative vision, we found a clear attempt to recover the category of dar al-Islam, re-elaborating its universalistic premises. In his discourse, a full realisation of humanity necessitates the universalisation of Islam and the rejection of animalism and unbelief. This is the path that mankind should follow in order to abide by the supreme law of God as well as to its own humanity. The universal implementation of Islam as being consubstantial to the full realisation of humanity expresses what I define as a state or plane of necessity - where Islam is taken here to reflect the ideal of both the Islamic ummah (subjective formation) and its territorial and juridical transposal in the dar al-Islam (spatial representation). Now, if the state of necessity presupposes the ideal universalisation of dar al-Islam, the contingency of history entails that such universalisation is hampered by the very presence of nonMuslims. Here, dar al-Islam figures in the contingency of history as a partial reality competing with some sort of outside, the dar al-harb. I define the plane where historical events take place and where dar al-Islam and dar al-harb appear as historical particular or partial manifestations as the state of contingency.

Since in Qutb's eschatological vision the full realisation of humanity requires establishing Islam as a totality, dar al-harb can only appear as a temporary historical 
manifestation that dar al-Islam should be able to absorb. Such a movement would allow dar al-Islam to dismiss its particular character in the state of contingency assuming a permanent and universal dimension and thereby affirming the state of necessity. In other words, the dar al-Islam should be able to subsume the dar al-harb in the contingency of history. This would allow dar al-Islam to figure as an allencompassing totality. But should this happen, it would mean that the state of contingency and the state of necessity coincide and that the necessary ideal of Islamic universalism would have found a breach in history. Hence, in principle, it is the inclusive nature of the pan-Islamic theoretical model that connects necessity and contingency. In this respect, dar al-harb stands as a simulacrum that appears on the surface of an inclusive dynamic. By "dynamic", I mean quite literally the "force" which promotes change within a certain process. The term simulacrum refers then to the very existence of dar al-harb as a transient historical "phenomenon" in the inclusive movement leading to the universalisation of Islam. This implies that dar alharb is seen by the viewpoint of Islamic universalism as something that appears temporarily but that, sooner or later, will necessarily be absorbed by dar al-Islam. It can thus be said that, despite the fact that it figures as a contingent manifestation, dar al-harb already expresses the Islamic universality as a form of potentiality.

Such a movement can best be illustrated by resorting to the topology of the Möbius strip. It is well known that the Möbius is a three-dimensional figure that, like other topological figures, subverts Euclidean ways of representing space. Unlike simple shapes of Euclidean geometry where all points are set in a plane and neat distinctions can be drawn between the internal and the external, this figure problematizes all referents of interiority and exteriority. Although it seems to embody a two-sided dimension, its structure has only one side and only one boundary component: by travelling on one side, one ends up on the other side of the strip. Because of their properties, Euclidian figures can conveniently be used to illustrate the spatial dimension of those political formations whose discursive organisation relies on a binary logic. For instance, the space of nation can be represented through the delineation of a circle with its circumference epitomising the national border and therein allowing for a neat (though paradoxical on a substantial level) separation between the inside of the nation and its respective outside. The stronger the demarcation of such a circumference is imagined, the more hypertrophic and rigid the distinction between the national inside and its outside (e.g., radical forms of nationalisms). What is distinctive about the Möbius, instead, is that although the very organisation of space through referents of interiority and exteriority is preserved, this is done exposing it to change, inclusivity and contingency. While the two sides of the Möbius can be clearly distinguished at any one point, in their local dimension, when the strip is traversed and assumed as a whole it becomes clear that they are in fact continuous. In spite of the static dimension the circle, it is time that allows the two sides of the strip both to emerge and to become indistinguishable along the movement employed to traverse the structure.

When using this topological model, dar al-harb emerges as a transient, particular, contingent and historical manifestation lying on one of the two apparent sides of the 
strip. The other apparent side of the strip is incarnated by dar al-Islam which, similarly, figures here as a transient, particular, contingent and historical manifestation. Both dar al-harb and dar al-Islam express - as the two apparent sides of the strip - the state of contingency. Dar al-harb figures, however, as a simulacrum, which is deemed to disappear because the movement along the strip allows dar alIslam to emerge clearly, thereby absorbing dar al-harb and enacting the inclusive, necessary, and permanent movement of Islamic universalism. Dar al-Islam therefore reflects a twofold dimension. On the one side, it coincides with one of the two apparent sides of the strip, which it continuously competes with and absorbs dar alharb at the level of contingency. On the other side, it also coincides with the overall inclusive surface of the Möbius strip itself, which reflects the state of necessity permanently incorporating historical contingency. The dar al-Islam thus functions as a connecting point between necessity and contingency. The integration of dar al-harb within the contingent domain of dar al-Islam, and the consequent subsuming of contingency by necessity within a permanent and inclusive movement constitutes what I define as Islamic inclusive universalism. Given Qutb's normative formulation of Muslim subjectivity in the form of the Islamic society, how is territoriality defined in relation to such a speculative framework?

In line with traditional universalistic discourses, Qutb's spatial re-articulation of dar al-Islam maintains an inherently universal and necessary character, paralleling and sustaining the fluid and universal notion of the Islamic community. In this respect, Qutb asserts dar al-Islam as the only possible form of territoriality that Muslims should conceive as acting against communal or national forms of identification:

A Muslim has no country except that part of the earth where the Shari'ah of God is established [...] a Muslim has no nationality except his belief, which makes him a member of the Muslim community in Dar-ul-Islam (Qutb 1964/2006, 119).

Since, as we have seen, the establishment of God's sovereignty alone allows "humanity" and "freedom" to be expressed, the dar al-Islam reflects the necessary condition for mankind to exist; that is, to develop, collectively, its very qualities of "humanity" and "civilisation" (Qutb 1964/2006, 124). Such an understanding of dar al-Islam renounces any physical conceptualisation of territoriality and stands as the immaterial surface of a new communitarian and spiritual linkage. The ecumenical reference to "God" or "Islam" now subsumes old distinctions of blood, culture and geography:

Only this is Islam, and only this is Dar-ul-Islam - not the soil, not the race, not the lineage, not the tribe, and not the family [...] The homeland of the Muslim, in which he lives and which he defends, is not a piece of land; the nationality of the Muslim, by which he is identified, is not the nationality determined by a government; the family of the Muslim, in which he finds solace and which he defends, is not blood relationships (Qutb 1964/2006, 124). 
This connection among three main signifiers, "necessity", "spirituality" and "universality" sustains the particular connotation that the dar al-Islam assumes vis-àvis the national concepts of "territory". From this perspective, it should be stressed that Qutb acknowledges the attempts made by imperial, national or other alternative political systems to supersede divisions among their constituencies. Such experiences, however, are rated as failures, which produced new discriminatory distinctions. The domain of Islam alone can succeed in the realisation of its universal message:

Various societies have also appeared in modern times. For example, consider the British Empire. It is like the Roman society to which it is an heir. It is based on national greed, in which the British nation has the leadership and exploits those colonies annexed by the Empire. The same is true of other European empires [...] Communism also wanted to establish a new type of society, demolishing the walls of race and color, nation and geographical region, but it is not based on "human relationship" but on a "class system" [...] Islam, then, is the only Divine way of life which brings out the noblest human characteristics, developing and using them for the construction of human society (Qutb 1964/2006, 50-51).

If "necessity", "spirituality" and "universality" define the meaning of dar alIslam, how does Qutb characterise the very existence of dar al-harb, especially in the face of the national idea of the outside? We have seen that Qutb unambiguously rejects the very notion of nationality and its inner dichotomous distinction based on race, lineage and geography, constructing dar al-Islam as an immediate presence whose nature is necessary and self-asserting, as Nietzsche might say, as a "triumphant yes-sayer" to itself (Nietzsche 1887/1989, 19). It is true that an outside, dar al-harb, is also represented here, but it emerges by way of a secondary movement that is not assumed as a necessary condition for the presence of Islam itself. The national territory's binary structure instead entails a primary definition of the domain of the outside against which, in the guise of an absolute opposition, it is possible to think of the inside as a closed totality. While the national territory assumes its respective outside as a constitutive and irreducible exteriority, the dar al-harb remains a contingent and transient manifestation within history to be integrated, at some point in time, by Islam.

In a crucial passage, Qutb reasserts the traditional "inclusive" notion of dar alIslam as able to integrate and articulate internal differences while, at the same time, stating the presence of non-Islamic domains, the dar al-harb, on a very factual level:

The Muslim's country has not been a piece of land, but the homeland of Islam (Dar-ulIslam) [...] This Islamic homeland is a refuge for any who accepts the Islamic Shari'ah to be the law of the state, as is the case with the Dhimmies. But any place where the Islamic Shari'ah is not enforced and where Islam is not dominant becomes the home of Hostility

\footnotetext{
${ }^{2}$ This schema aligns to Nietzsche's distinction between "Good and Evil" and "Good and Bad"; that is, between the dialectical logic of slave morality with ressentiment requiring a first, "necessary direction toward the outside" and the values of a pre-Christian aristocracy focusing of self-affirmation (Nietzsche 1887/1989, 19).
} 
(Dar-ul-Harb) for both the Muslim and the Dhimmi. A Muslim will remain prepared to fight against it, whether it be his birthplace or a place where his relatives reside or where his property or any other material interests are located (Qutb 1964/2006, 124).

It is clear from the passage above that Qutb acknowledges traditional views of Islamic territoriality, for the dar al-Islam is said to embody within its jurisdictional domain not only Muslim constituencies but also the dhimmi: non-Muslims living in Islamic-ruled countries and enjoying forms of legal protection behind special taxation. At the same time, the dar al-harb of non-Islamic ruled countries is acknowledged as a matter of fact. Since the dar al-Islam must reflect the universality of Islam, no outside would be possible on a necessary level. Thus dar al-harb can only appear as a contingent manifestation that, sooner or later, will need to be subsumed within the universality of Islam, so losing its external character and becoming either an internal difference in the form of the dhimmi or a form of Muslim singularity. As Middle East scholar Majid Khadduri puts it: "dar al-harb could not possibly attain a normal or permanent status unless its inhabitants either adopted Islam or accepted the status of the tolerated religions" (Khadduri 1955/2006, 145).

It should be pointed out, however, that within the multiplicity of discourses informing the Islamic jurisprudential thought, a middle ground - the dar al- 'ahd (land of truce) - was acknowledged as a practical device to ensure peace and stability with non-Muslim lands and reduce the cost of a permanent jihad. It consisted of those lands with which a formal agreement was made, guaranteeing the protection of Muslims under foreign rule or the protection of non-Muslim regions behind tributary taxation or within any area in which open warfare was absent (Salmi 1998). This third temporary division remained subject to perpetual renewal as the limits between dar al-Islam and dar al-'ahd were never formalised, thereby moderating the polarity between dar al-Islam and dar al-harb. Moreover, a series of administrative devices were elaborated across time to substantiate the inclusive and universal character of dar al-Islam, tempering its potential antagonism, and ensuring a form of harmonious stability. This is best demonstrated by the millet system, consisting of non-Muslim communities in the Ottoman Empire - such as the Greek, the Armenian Orthodox, and the Jews - that were incorporated into the institutional system of the Empire and provided with the right to observe their religious affiliations and govern their internal affairs (Karpat 1980; Tatsuo 1999). These devices allowed for official recognition of possible spaces of exteriority that were constantly reproduced and formally acknowledged. In principle, they did not undermine the inclusive structure of Islamic universalism as their inclusion in the domain of Islam was maintained ideally and postponed somewhere in the future, as if time would have naturally drove, at some indefinite point, the dynamic topological shift from contingency to necessity. Although Qutb expresses a more radical stance in this regard, as no mention is made of the existence of $d a r$ al- 'ahd, the inclusive structure of this dynamics remains a potential offshoot of this model. A form of inclusive differentiation here is constantly re-produced in the antagonistic form of dar al-harb or in the more compromising and 
mediating form of dar al- 'ahd, which does not obstruct the universalistic projection of a full-humanity.

With this overall structure in mind, it is crucial to highlight that an even stronger polarisation could mark the "contingent" tension that Qutb's normative vision of Islamic universalism instantiates between dar al-Islam and dar al-harb. This could happen if the temporary antagonism between dar al-Islam and dar al-harb "freezes" into a definitive and irremediable counter-position that would ultimately interrupt the inclusive relation between necessity and contingency. I contend that such a risk clearly emerges when Qutb introduces his notion of jahiliyyah and undertakes a critical analysis of the contemporary human condition.

\section{SAYYID QUTB'S DESCRIPTIVE VISION}

As I mentioned above, what appears to be a dynamic form of antagonism in Qutb's normative vision is somehow frozen as Qutb switches his focus to an analysis of his contemporary times. It is here that a "descriptive register" is adopted:

If we look at the sources and foundations of modern ways of living, it becomes clear that the whole world is steeped in Jahiliyyah, [Ignorance of the Divine guidance] [...] It is now not in that simple and primitive form of the ancient Jahiliyyah, but takes the form of claiming that the right to create values, to legislate rules of collective behavior, and to choose any way of life, rests with men, without regard to what God has prescribed (Qutb 1964/2006, 11).

A few caveats are needed in respect to the crucial passage above. First, it is clear that Qutb is no longer defining how humanity should be on an ideal and normative level, but is indeed describing how things on a factual and historical level are or appear. The ideal of the Islamic society with all its creativity, humanity, and ability to integrate difference (e.g. through the legal recognition of the dhimmi) is here contrasted with the acknowledgment that "reality" is completely un-Islamic (jahili), animalistic, and primitive. The difference between the ideal and reality, the Islamic society and jahiliyyah is best represented through the distinction between a normative and a descriptive level in Qutb's work. A second point to be stressed from the passage above regards the very notion of jahiliyyah. Unlike pre-Islamic ignorance, contemporary jahiliyyah is described first and foremost by its immanent character. That is, jahiliyyah figures as the social condition under which God's will is replaced with the immanency of human decisions, with the claim "that the right to create values [...] rests with men". Finally, and critically, the transient and particular appearance that dar al-harb covers in Qutb's normative vision undergoes a sort of crystallisation and pervasive expansion to the extent that "the whole world" is now "steeped in Jahiliyyah".

The notion of jahiliyyah to describe contemporary reality had already been used within the realm of Islamist discourse. For instance, the Pakistani Islamist thinker Syed Abul A'ala Mawdudi (1903-1979) had already deployed the classic concept of 
jahiliyyah to describe the domain of what, in traditional terms, was dubbed dar alharb. Equating the notion of dar al-harb, jahiliyyah stood for Mawdudi as a historical, partial and transient manifestation of unbelief to be re-absorbed by dar alIslam through the very revival this thinker was advocating. Although Qutb was "an avid reader" of Mawdudi (Calvert 2010, 213) and there is common tendency among scholars to emphasise Mawdudi's genealogical influence on Qutb's more radical aspects as developed during his time in prison (Moussalli 2005; Demant \& Engineer 2006), a difference needs to be emphasised between the two, which strongly affects the way in which forms of political antagonism are considered. Unlike Mawdudi, Qutb's understanding of jahiliyyah should not be seen as a condition somehow informing the space of dar al-harb. We saw that in Qutb's normative vision, dar alharb stands as a transient and partial manifestation competing with dar al-Islam in the plane of contingency. On a descriptive level, instead, Qutb's notion of jahiliyyah implies that the Islamic community itself is erased and replaced by an overarching and absolute un-Islamic surface, thus disappearing from the plane of contingency. In this sense, jahiliyyah stands as an all-encompassing reality in the contingency of history supplanting the Islamic society entirely and becoming a sort of totality, a universality whose omnipresence does not acknowledge any outside:

The jahili society is any society other than the Muslim society; and if we want a more specific definition, we may say that any society is a jahili society which does not dedicate itself to submission to God alone, in its beliefs and ideas in its observances of worship, and in its legal regulations. According to this definition, all the societies existing in the world today are jahili [emphasis mine] (Qutb 1964/2006, 80).

Interestingly, Qutb differentiates between several kinds of jahili societies, each one dominated by a particular discourse ("communism", "paganism", "nationalism", etc.). Within the global realm of jahiliyyah, we also find "Jewish and Christian societies":

All Jewish and Christian societies today are also jahili societies. They have distorted the original beliefs and ascribe certain attributes of God to other beings (Qutb 1964/2006, $81)$.

Indeed, I showed that Qutb's normative vision includes Christians, Jews and the broader category of dhimmi under the domain of dar al-Islam. Now that Qutb is assuming a descriptive register the Jewish and Christian societies are irremediably inscribed in the omnipresent realm of jahiliyyah. This is a sign of Qutb's adoption of an extreme position when assessing the compatibility to Islam of existent human societies. Even more symptomatic of this position, however, is the ultimate inclusion of Muslim societies themselves within the overarching realm of jahiliyyah:

Lastly, all the existing so-called "Muslim" societies are also jahili societies [...] Although they believe In the Unity of God, still they have relegated the legislative attribute of God to others and submit to this authority, and from this authority they derive their systems, 
their traditions and customs, their laws, their values and standards, and almost every practice of life (Qutb 1964/2006, 82).

Although connected, the descriptive register enacts a structural transformation of normative register, altering its inclusive system. On a broad perspective, such a transformation is informed by a logic of replacement, as the dar al-Islam is now replaced by an overarching "jahiliyyah" in the plane of contingency. This entails that the Islamic community disappears as a partial and contingent manifestation, becoming an absolute absence. So, while the distinction between a necessary and a contingent level is maintained, the inclusive and universalistic harmony connecting the two levels is interrupted. On the one hand, the omni-presence of jahiliyyah stands as a totality at the level of contingency. Dar al-Islam is thereby relegated to the plane of necessity alone, resulting in the loss of its quality as a fundamental connecting point between the two levels. The absolute universality of jahiliyyah in the state of contingency now opposes the universality of the Islamic society in the state of necessity. On the other hand, the fact that dar al-Islam stops appearing as a concrete historical manifestation means that it can now only be thought of as a promise to be realised. A virtualisation of the Islamic ummah - its figuring both as an ideal and a potentiality - accompanies the universalisation of the jahiliyyah.

In place of the inclusive pan-Islamic model of the Möbius strip that connected necessity and contingency, we now find the overlapping of two circles expressing two closed totalities - two universalities. On one side jahiliyyah, which is universalised thereby occupying the whole spectrum of contingency. On the other side, the Islamic community, which disappears as a partial manifestation at the level of contingency, and stands as a virtual universality, i.e. a pure potentiality in the state of necessity. The overlapping of the two circles reflects the disjunction between the planes of necessity and contingency, which is established as an effect of the all-encompassing presence of jahiliyyah in the state of contingency. In figurative terms, the emergence of two overlapping circles marks the organisation of a strongly polarised spatial model, somehow aligned to the sort of binary structure that informs political discourses like nationalism. In the next pages, however, some important differences will be traced in order to identify the specificity of what could be called a jahili form of antagonism. It is important to highlight that the structural relation between the descriptive and the normative registers finds expression in its figurative representation. The return to a Euclidian plane characterised by the emergence of two circles resonates with the kind of geometric alteration that is enacted when the Möbius strip is cut down in the middle. The result here is that the strip is transformed into a single loop with very different topological qualities as it now has two sides instead of one. Metaphorically, the passage from the normative to the descriptive register should be seen as a discontinuous transformation of the topological model informing the former.

Before considering the antagonistic effects that the descriptive register enacts, it is useful to point out that the virtualisation of Islamic society is by Qutb made explicit: 
According to our unvarying definition of civilization, the Islamic society is not just an entity of the past, to be studied in history, but it is a demand of the present and a hope of the future. Mankind can be dignified, today or tomorrow, by striving toward this noble civilization, by pulling itself out of the abyss of Jahiliyyah into which it is falling [...] The values to which we referred above as human values were never attained by mankind except in the period of Islamic civilization (Qutb 1964/2006, 103).

Except for the period of Islamic civilisation, the society of Islam in which human values are expressed has been substantially absent from the contingent plane of history. In the face of the "the abyss of Jahiliyyah", the Islamic society stands as an absent object of desire, "a demand of the present and a hope of the future" [my emphasis]. With this assertion in mind, if history has testified to the gradual universalisation of jahiliyyah and the consequent virtualisation of the Islamic society, which kind of antagonistic relations can be traced for Muslims?

Two differing attitudes stem from this scenario. First, to strive on behalf of the Islamic society could mean to re-establish dar al-Islam in the plane of contingency, to assert its presence vis-à-vis its living absence, to promote its actuality vis-à-vis the ultimate virtuality in which the Muslim community has been confined (actualising the potential of such an ideal), and, finally, to re-establish Islam as an inclusive universality. This would mean recovering the connecting function of dar al-Islam ensuring its simultaneous presence in the state of contingency and in the state of necessity. The osmotic relation between necessity and contingency would thereby be re-ensured, and the Islamic universalism of Qutb's normative vision would be reaffirmed. Secondly, to strive on behalf of the Islamic society could implicate assuming the polarisation between Islam and jahiliyyah as definitive, so cementing the dualism between necessity and contingency. Should this happen, the antagonism of Qutb's descriptive vision would thus have been crystallised, and its normative universalism renounced. A radical antagonism would survive only, with the effect that resistance to jahiliyyah would no longer aim at re-establishing the presence of Islam in the contingent dimension of history, in "the here" where concrete political interests can be posited and some form of compromise can always been found; rather, it would endeavour to gain salvation and purification in "the hereafter", where the ideal of the Islamic society can only be realised. Hence, the Muslim community in the form of a virtual object of desire based on a millenarist and puritanical vision in a number of contemporary religious movements.

Differences occur in regard to the conceptualisation of Islamic revival as a manner in which life is to be transformed for some and access to the hereafter is to be attained for others. As far as Qutb's position is concerned, a militant and "assertive" request for "revival" takes precedence in his texts over the apocalyptic nuances that very often also appear between the lines. This means that the normative vision of Qutb overcomes the descriptive one. Despite the apocalyptic dimension surrounding contemporary life, for the true believer the irreducible task remains to assert the normative ideal of Islam, the need to recover the harmonious and inclusive universality of dar al-Islam. Hence the opening utterance at the beginning of his 
book: "At this crucial and bewildering juncture, the turn of Islam and the Muslim community has arrived" (Qutb 1964/2006, 8). It is here that Qutb's notion of jihad, the "effort" or "struggle" in the path of Islam, emerges as a central tenet, standing as the duty to revive Islamic society in history. That is, to fight in the way of God, calling for the soul of men "so that there may not remain any wall between Islam and individual human beings" (Qutb 1964/2006, 72)' and fighting those "institutions and traditions which limit man's freedom of choice" (Qutb 1964/2006, 75).

A last point to be discussed concerns the way Qutb conceptualises the relation between the all-embracing environment of jahiliyyah and those believers who strive to restore Islamic society. Qutb establishes here a fundamental disjunction between "believers" and "true believers". Such a distinction, in itself, is not a new one, for a common discursive practice among Islamist movements has been to conceive of Islam as a dormant force within Muslim societies to be revived by militant and zealous believers. On the one side, we find the "partial Muslims". That is, the majority of Muslims confining religion to a private affair or to a spiritual, cultural and ritual dimension. Thereby living Islam "merely as a part of a section of their whole life" and drawing on other sources for the remaining aspects of their life (Mawdudi 1985, 116-117). On the other side, we find "true Muslims", those who live the Islamic message as an all-encompassing dimension affecting any aspect of everyday life, who deploy activism to revive the social function of Islam.

Qutb makes this distinction more extreme. In spite of traditional views where all "Muslims" share the common destiny of being part of an existent Muslim community, in Qutb's descriptive vision Muslim societies themselves are relegated to jahiliyyah whilst dar al-Islam disappears from the contingency of history. This certainly means that "partial Muslims" - regular believers who, for Qutb, disregard the integral and exclusive dimension of Islam in life - are inscribed in the omnipresent domain of jahiliyyah. But would the "all-encompassing" presence of jahiliyyah also mean that "true Muslims", those who follow Qutb's message to fight to restore Islamic universalism, are themselves a jahili manifestation as long as they live in the jahili contingency of history? This is a crucial point, for it compels Qutb to formulate some notion of Muslim community in the state of contingency of his descriptive vision. The problem could be formulated as follows: if the ummah is absent from the plane of contingency, if it stands only as a demand, how should true believers be thought of considering that they all are living parts of the universal realm of unbelief? How should their dispersed and "fragmented" position as individuals in the "ocean of jahiliyyah" be accounted?

In answering this question, it would seem that true believers "anticipate" the Muslim community to come, realising a virtual illusion of presence of the ummah in life. The "community" of the true believers does not eradicate the general assessment of the state of contingency being a universal expression of jahiliyyah, for it stands as a simulacrum; that is, a phenomenal apparition, a virtual anticipation of the Muslim community to come. Although Muslim society remains a hope to be realised, it is the community of "true believers" that allows Muslims striving in the path of Islam to keep identifying with that promise, establishing some form of connection with that 
very object of desire in the state of contingency. Hence the logic of replacement found in Qutb's descriptive model. While the dar al-harb in his normative vision figured as a simulacrum at the level of contingency, ultimately expressing Islamic universality as a potentiality, the position of simulacrum at the level of contingency is now covered by the community of true-believers. This community appears as the virtual anticipation of a promise, the potentiality of the ummah, the Muslim community to come.

To refer to the ensemble of dispersed true believers in the ocean of jahiliyyah, Qutb deploys the notion of "vanguard", which parallels the idea of a "virtuality" of the ummah:

How is it possible to start the task of reviving Islam? It is necessary that there should be a vanguard which sets out with this determination and then keeps walking on the path, marching through the vast ocean of Jahiliyyah which has encompassed the entire world. During its course, it should keep itself somewhat aloof from this all-encompassing Jahiliyyah and should also keep some ties with it [...] I have written "Milestones" for this vanguard, which I consider to be a waiting reality about to be materialized (Qutb 1964/2006, 12).

It is through a "vanguard" to be "somewhat aloof" from an "all-encompassing Jahiliyyah" that Qutb manages to articulate the anticipation of the community to come. For such a community, this requires a paradoxical status as best evidenced by the interesting expression "somewhat aloof". The vanguard is both immersed in jahiliyyah, the contingency of history, yet beyond it. By way of a virtual anticipation, such a community represents its very opposite: the Islamic community to come. It is necessary to assume the position of a single true believer as a highly dispersed and fragmented one, for he or she is surrounded by an "all-encompassing" jahili environment and only connected with other true believers in the virtual conception of the vanguard. This dispersed position needs furthermore to be maintained even in intimate relations such as familial ties, as "Islam" requires exclusive loyalty. In case of the believer's parents declaring "their alliance with the enemies of Islam", in fact, Qutb's does not hesitate to state that "all the filial relationships of a Muslim are cut off and he is not bound to be kind and considerate to them" (Qutb 1964/2006, 119).

This approach finds expression in the articulation of the signifier "vanguardism" that groups like Hizb and al-Muhajiroun (an upshot of Hizb ut-Tahrir) have promoted in the past by presenting themselves as an "elite vanguard" of the Islamic society yet to be founded (Habeck 2006, 144). In his study of "neo-fundamentalism", a term used to refer to neo-orthodox groups such as al-qaeda, al-Muhajiroun and Hizb ut-Tahrir, French scholar Oliver Roy suggests precisely this kind of pattern, describing the vanguard community of true believers as a mental attitude, an immaterial and "virtual" presence:

Radical militant jihadists fight at the frontier to protect a centre where they have no place. They fight not to protect a territory but to re-create a community. They are besieged in a fortress they do not inhabit. This empty fortress syndrome is related to the pathological 
dimension of their jihad. Contemporary mujahedin are pessimistic because they know that there is no longer a fortress to protect, that the enemy is in the fortress (Roy 2004, 289).

This emphasis on "vanguardism" and "jahiliyyah" testifies to the influence that Qutb's vision continues to exert upon Islamist movements. In the global scenario following Qutb's death, his complex vision remains as a major source of inspiration for new Islamist trajectories, marking a major turning point in the history of Islamism.

\section{CONCLUSION}

This article pursued a topological reading of Sayyid Qutb's most influential work, Milestones, aimed at unfolding the spatial complexity of Qutb's political theology and exposing his antagonistic dynamics. In doing so, the article strived to uncover Qutb's universalistic dimension in what I termed a "normative" register, assessing its counter-hegemonic potential vis-à-vis the discourse of the nation, a discourse that plays a dominant role in global politics. This article went further, by including an analysis of Qutb's particular understanding of his contemporary world in what I called a "descriptive" register. On a broad perspective, I contended that the topological disjunction between a normative and a descriptive level is central to distinguish between different forms of antagonism in this seminal text.

When considering philosophical and political debates on universalism, I mentioned earlier that research interest in the West has renewed attention to this concept in recent years. Non-western conceptions of universality, however, have remained substantially unexplored. This can perhaps be explained by the feeling that some sort of unintellegibility marks the tension/relation between western and nonwestern forms of knowledge. When comparing Qutb's and continental universalistic perspectives, for instance, it is true that differences cannot be underestimated. Milestones' universalism reveals an eschatological idea of world order where Islamic territoriality, dar al-Islam, (ideally) absorbs its non-Muslim outside (dar al-harb), realising a new form of human association which transcends closed, exclusive communities based on soil, nationhood, blood, culture and so on. But while dar alIslam upsets and broadens previous groupings, it might require commitment to a new set of substantive rules and norms: a commitment to a shared ethical form of life. Conversely, universality in the Pauline tradition reveals a kind of universal space set against this kind of ethical grouping. The contemporary interest in Paul seems to lie precisely in the replacement (or destruction) of law with love; that is, Pauline universality appears as an empty or content-less form of association. Hence, for instance, Badiou's and Žižek's respective emphasis on the empty set and negativity.

The foregoing analysis has given emphasis to the crucial symbolic function that God plays in the articulation of Qutb's discourse. In resorting to God, Qutb is keen in positing some substantial justification for the foundation of his philosophical edifice. The attempt to re-interpret modern sovereignty in divine terms, allowing for an 
upward re-directing of it from humankind to God, and the very ethical and normative appeal pervading his conception of humanity in the form of a "realistic utopia" (March 2010, 192), bear witness to the crucial mobilizing power that an imaginative symbolism predicated upon the discourse of prophecy assumes in his vision. On a broad perspective, such a mobilising function is fully aligned to what Muhammad Azadpur has recently described as a traditional objective in Islamic philosophy aimed at the "realization of a human exemplar as the standard of wisdom" (Azadpur 2011, 4). According to Azadpur, this objective "is constitutive of the philosophical activity as such - the transformation of the self for the sake of knowledge" and informs the particular project that Greeks themselves reserved for philosophy, notwithstanding common interpretations of Greek philosophy as a system of rational knowledge. What stands as unique in Islamic philosophy is for Azadpur the appropriation of this tradition "into a legacy of Islamic prophetology" (Azadpur 2011, 7). In the light of such an interpretation, therefore, Qutb's vision can be assumed as a philosophical project aimed at the transformation of the self in accordance with the precepts expressed in the religious discourse of prophecy. This is central to understand the crucial role that jihad plays for Qutb as an "effort" and a fight in the "way of God", allowing for the moulding of a new believer devoted to the restoration of the Islamic society. By pursuing the cultivation of the soul through a prophetic imaginative symbolism leading to the liberation from the mundane and culminating in an experience of the divine, Qutb's hermeneutics fully adheres here to the Islamic philosophical legacy that Azadpur discusses. What needs to be emphasised, however, is that Qutb seems to assume religious faith as the immediate and necessary condition to interpret and access the fundamental link between prophecy and philosophy. Such a link is also constitutive of both the very descriptive "critique" that Qutb poses towards his historical era, and the substantial judgment that he ascribes to any possible conceptualisation of power and authority. Hence the symbolic power that the discourse of revelation covers in Qutb's rejection of immanentist accounts of sovereignty. Hence also the fundamental counter-hegemonic tone of Qutb's political theology, a tone that both reflects and mobilises the influence that theologicalpolitical questions have traditionally exerted upon ideas of power, sovereignty, the worldly and the spiritual and the relationship between political and religious authority - an influence that current debates on political theology in its Christian and European variants have similarly contributed to highlight.

In accounting for the differences at work between Qutb's universalism and other ways of engaging with ideas of political universalism, immediate emphasis is given therefore to those forms of incommensurability that seem to mark the relation between knowledges. This is not, however, to disregard the very possibility of cultural translation between these traditions, dismissing any potential for creative and productive exchange. As Boaventura de Sousa Santos recalls: "incommensurability does not necessarily impede communication and may even lead to unsuspected forms of complementarity" (Santos 2007, 38). The attempt to offer a topological insight into Qutb's thought, highlighting the philosophical dimension of his figure, was fundamentally inspired in this direction by the persuasion that Milestones' 
universalistic model can provide new material for investigation in continental philosophy. Although an exploration of Qutb's contribution to specific debates as well as a comparative assessment exceeded the scope of this article, the analysis of Milestones can serve as a first step in examining the notion of universalism in different traditions. This can help highlight the ideological potential that this concept embodies in a globalised world. If anything, this article showed that Qutb's postcolonial revitalisation of universalism parallels attempts in the critical humanities to endorse forms of universalistic space marked by an anti-national and counterhegemonic stance. Like critical accounts of universality, Qutb furthermore pursues such an endeavour by articulating a spatial model able to integrate differences and preserve forms of political litigation.

Such a tension was crucially represented through the topological models developed in this article, which could be re-elaborated in the analysis of convergent forms of political subjectivity. When uncovering Qutb's universalistic organisation of Islamic space, for instance, I highlighted the ability of dar al-Islam to instantiate an inclusive and structural relation with the phenomenal and contingent character of dar al-harb as well as with the mediating quality of dar al- 'ahd. In this regard, a potential adaptability of this spatial model could be explored to those continental conceptions of universality that preserve forms of conflict and social justice pointing to an ongoing reproduction, acknowledgment and identification with the realm of the inhuman, the non-citizens. If considered beyond Qutb's eschatological implications, reverting the emancipatory focus on his inclusive structure - with the domain of Islam becoming the universalistic space of the common, the multitude, or a global citizenship, and the non-Islamic outside epitomising the ever-emerging and positivised realm of the excluded, those "who have no voice" (Ranciére 1999, 208) such a topological representation could be assumed as a useful geographical model for imagining the kind of spatial configuration that content-less forms of association instantiate.

Finally, this article has exposed the most radical traits of Qutb's vision, unravelling a different spatial model in Milestones' descriptive register, one that abdicates to the ethos of his universalistic ideal in favour of a hypertrophic organisation of space and antagonism. We could observe here a more rigid configuration, one in which the universalisation of jahiliyyah and the virtualisation of the ummah seclude the very possibility of an encounter with the outside, allowing for the emergence of a vanguardist conception of resistance so central to western radical traditions of political activism. It is these variations in Sayyid Qutb's political theology that this article disclosed, highlighting the complexity and richness of a controversial as much as influential thinker.

\section{ACKNOWLEDGEMENTS}

The research leading to these results has received funding from the European Research Council under the European Union's Seventh Framework Programme 
(FP7/2007-2013) / ERC grant agreement $n^{\circ}$ 249379. I would like to express my special thanks to the two anonymous referees of the journal Comparative Philosophy for their inputs and useful observations.

\section{REFERENCES}

al-Banna, Hasan (appeared in the early 1940s), The Message Of The Teachings (Cairo: n.p.); Available from: <http://thequranblog.files.wordpress.com/ 2008/06/_3_-the-message-of-the-teachings.pdf>, [Accessed December 2013].

Asad, Talal (2012), Formations of the Secular: Christianity, Islam, Modernity (Stanford, Calif.: Stanford University Press).

Azadpur, Muhammad (2011), Reason Unbound: On Spiritual Practice in Islamic Peripatetic Philosophy (New York: SUNY Press).

Badiou, Alain (1997/2003), Saint Paul: The Foundation of Universalism (Stanford, Calif.: Stanford University Press).

---- (2006), Metapolitics (London: Verso).

Balibar, Etienne (1991), "Racism and Nationalism", in Etienne Balibar and Immanuel Wallerstein (eds.): Race, Nation and Class (London: Verso).

Calvert, John (2010), Sayyid Qutb and the Origins of Radical Islamism (New York: Columbia University Press).

Coombs, Nathan (2009), "Christian Communists, Islamic Anarchists? - part 1", International Journal of Žižek Studies 3 (1): <http://zizekstudies.org/index.php/ ijzs/article/view/153/269>.

Delanty, Gerard (1995), Inventing Europe: Idea, Identity, Reality (Basingstoke: Macmillan).

Demant, Peter R. \& Engineer, Ashgar Ali (2006), Islam vs. Islamism: The Dilemma of the Muslim World (Westport, Conn.; London: Praeger).

Euben, Roxanne L. (1999), Enemy in the Mirror: Islamic Fundamentalism and the Limits of Modern Rationalism (Princeton, N.J.: Princeton University Press).

Foucault, Michel (1977-1978/2007), Security, Territory, Population: Lectures at the Collège de France, 1977-1978 (Basingstoke: Palgrave Macmillan).

Habeck, Mary R. (2006), Knowing the Enemy: Jihadist Ideology and the War on Terror (New Haven: Yale University Press).

Haddad, Yvonne Y. (1983), "Sayyid Qutb: Ideologue of Islamic Revival", in John Esposito (ed.): Voices of the Islamic Revolution (Oxford: Oxford University Press).

Hardt, Michael \& Negri, Antonio (2000), Empire (London: Harvard University Press).

Isin, Engin F. (2012), "Citizenship After Orientalism: An Unfinished Project", Citizenship Studies 16 (5-6): 563-572.

Karpat, Kemal H. (1980), "Millets and Nationality: The Roots of the Incongruity of Nation and State in the Post-Ottoman Era", in Benjamin Braude and Bernard 
Lewis (eds.): Christians and Jews in the Ottoman Empire, The Functioning of a Plural Society (New York: Holmes \& Meier Publishers).

Khadduri, Majid (1955/2006), War and Peace in the Law of Islam (New Jersey: The Lawbook Exchange LTD).

Khatab, Sayed (2002), "Hakimiyyah and Jahiliyyah in the Thought of Sayyid Qutb", Middle Eastern Studies 38 (3): 145-170.

---- (2006), The Power of Sovereignty: The Political And Ideological Philosophy of Sayyid Qutb (London: Routledge).

---- (2009), The Political Thought of Sayyid Qutb: The Theory of Jahiliyyah (London: Routledge).

Lewis, Bernard, (1976), “The Return of Islam”, Commentary vol. I: 39-49.

Mandaville, Peter G. (2007), Global Political Islam (New York, NY: Routledge).

March, Andrew F. (2010), "Taking People as They Are: Islam as a 'Realistic Utopia' in the Political Theory of Sayyid Qutb", American Political Science Review 104 (1).

Mawdudi, Abul Ala (1985), Let Us Be Muslim (Leicester: Islamic Foundation).

Moaddel, Mansoor (2005), Islamic Modernism, Nationalism, and Fundamentalism: Episode and Discourse (Chicago: University of Chicago Press).

Mouffe, Chantal (2005), On the Political (Abingdon, Oxford: Routledge).

Moussalli, Ahmad S. (1992), Radical Islamic Fundamentalism: The Ideological and Political Discourse of Sayyid Qutb (Beirut, Lebanon: American University of Beirut).

Musallam, Adnan A. (2005), From Secularism to Jihad: Sayyid Qutb and the Foundations of Radical Islamism (Westport, Conn.: Praeger).

Nietzsche, Friedrich Wilhelm (1887/1989), On the Genealogy of Morals (New York: Vintage Books).

Parvin, Manoucher \& Sommer, Maurie (1980), "Dar al-Islam: The Evolution of Muslim Territoriality and Its Implications for Conflict Resolution in the Middle East", International Journal of Middle East Studies 11 (1): 1-21.

Qutb, Sayyid (1964/2006), Milestones (New Delhi: Islamic Book Service).

Ranciére, Jacques (1999), Disagreement (Minneapolis: The University of Minnesota Press).

Ranciére, Jacques (2007), On the Shores of Politics (London: Verso).

Roy, Olivier, (2004), Globalized Islam - Fundamentalism, Deterritorialization and the Search for a New Ummah (London: Hurst).

Salmi, Ralph H. (1998), Islam and Conflict Resolution: Theories and Practices (Lanham, Md.: University Press of America).

Santos, Boaventura de Sousa (2007), "Another Knowledge is Possible: Beyond Northern Epistemologies", Review XXX (1): 45-89.

Shepard, William E. (2003), "Sayyid Qutb's Doctrine of Jahiliyya", International Journal of Middle East Studies 35 (4): 521-545.

Soffar, Mohamed (2004), The Political Theory of Sayyid Qutb: A Genealogy of Discourse (Berlin: Köster). 
Tatsuo, Indue (1999). "Liberal Democracy and Asian Orientalism", in Joanne R. Bauer and Daniel A. Bell (eds.): The East Asian Challenge for Human Rights (Cambridge: Cambridge University Press).

Thomas, Megan C. (2010), "Orientalism and Comparative Political Theory", The Review of Politics 72 (4): 653-677.

Young, Robert JC (1995), Colonial Desire: Hybridity in Theory, Culture and Race (London: Routledge).

Žižek, Slavoj (1999), The Ticklish Subject - The Absent Centre of Political Ontology (London: Verso).

--- (2007), "Censorship today: violence, or ecology as a new opium for the masses": <http://www.lacan.com/zizecology1.htm>.

---- (2008a), Violence. Big Ideas, Small Books (New York: Picador).

---- (2008b), "Nature and its Discontents", SubStance 37 (3): 53-54. 